\title{
Earth as humans' habitat: global climate change and the health of populations
}

\author{
Anthony J McMichael*
}

\section{Abstract}

Human-induced climate change, with such rapid and continuing global-scale warming, is historically unprecedented and signifies that human pressures on Earth's life-supporting natural systems now exceed the planet's bio-geo-capacity. The risks from climate change to health and survival in populations are diverse, as are the social and political ramifications. Although attributing observed health changes in a population to the recent climatic change is difficult, a coherent pattern of climate- and weather-associated changes is now evident in many regions of the world. The risks impinge unevenly, especially on poorer and vulnerable regions, and are amplified by pre-existing high rates of climate-sensitive diseases and conditions. If, as now appears likely, the world warms by $3-5^{\circ} \mathrm{C}$ by 2100 , the health consequences, directly and via massive social and economic disruption, will be severe. The health sector has an important message to convey, comparing the health risks and benefits of enlightened action to avert climate change and to achieve sustainable ways of living versus the self-interested or complacent inaction.

Keywords: Climate Change, Sustainability, Population Health, Anthropocene

Copyright: (C) 2014 by Kerman University of Medical Sciences

Citation: McMichael AJ. Earth as humans' habitat: global climate change and the health of populations. Int J Health Policy Manag 2014; 2: 9-12. doi: 10.15171/ijhpm.2014.03
Article History:

Received: 24 December 2013

Accepted: 9 January 2014

ePublished: 11 January 2014

\section{Correspondence to:}

Anthony J McMichael

Email: tony.mcmichael@anu.edu.au
$\mathrm{H}$ uman-induced climate change is an extraordinary recent phenomenon; such rapid and sustained warming, and at global scale, is historically unprecedented. It is a potent signal that humankind is now living and consuming well beyond the planet's limits.

Natural changes in Earth's climate, sometimes tumultuous, have been part of Earth's evolution over 4.6 billion years. Those natural fluctuations are always present, but they have predominantly different causes from the amplified 'greenhouse' forcing that humans are now causing. The natural influences on climate include variations in solar activity, volcanic activity, and natural oscillations of regional climatic systems such as the El Nino Southern Oscillation (ENSO). The great majority of the world's climate scientists are now certain that the recent 3-4 decades of warming is both real and well above expectation $(1,2)$. Most are also confident, from specific geophysical 'fingerprints' associated with the warming, that most of the $0.7^{\circ} \mathrm{C}$ temperature rise since the 1950s has been due to human-induced increase in the concentration of heat-trapping greenhouse gases in the lower atmosphere, primarily carbon dioxide from fossil fuel combustion and land clearing.

Today, the combination of escalating human numbers, an expanding global consumer middle-class, intensified economic activity, and the dominant technologies are putting excessive pressures on the natural biophysical and ecological systems that comprise Earth's life-support system. Human-induced climate change is one such system now being disrupted-one manifestation of a larger syndrome of 'planetary overload' (3). Before mid-20th century, humans collectively could not generate enough greenhouse gas emissions to change the lower atmosphere's composition sufficiently to induce rapid and sustained warming. Now we can.

Globally, human pressures on these great natural systems now markedly exceed the planet's bio-geo-capacity. Around 1980 the crossover occurred, from humankind being able to live on nature's annual 'dividend' - that is, within the planet's biological and physical limits-to supplementing that dividend by consuming, depleting and degrading natural capital. The size of the human environmental footprint, globally, is now about $150 \%$ of Earth's bio-geo-capacity and rising; this is obviously not sustainable (4). The other manifestations include stratospheric ozone depletion, declining soil fertility, shrinking water stocks, loss of biodiversity, ocean acidification, and disruptions to the global cycles of nitrogen and phosphorus. This has shifted humankind into the so-called 'Anthropocene' geological epoch (5); humans are now a geological force, capturing at least onethird of the planet's net primary (photosynthetic) product and changing the functioning of the Earth system.

Since rudimentary agriculture first emerged around 10,000 years ago, human societies have sought more secure, betterfed, and comfortable lives. Over time they have re-engineered local environments, mostly for food production. Recently, our industrialised societies have succeeded spectacularly in terms of material and life expectancy gains, largely underwritten by the extraordinary subsidy of high-density, portable, and cheap energy from fossil fuels. However, some of that success is now turning sour as the erosion of environmental systems increasingly endangers the well-being, health, and survival of human populations, and other species (6).

\section{Climate change and human health}

The spectrum of risks to the health of whole communities and 
populations from climate change is wide and diverse. So, too are the social and political ramifications. There are three broad causal pathways by which changes in climate affect human health (7):

1. Primary, direct-acting, climatic-environmental exposures. For example, the health consequences of exposure to excessive heat and the physical hazards of extreme weather events.

2. Secondary health risks resulting from less direct pathways involving disruptions/changes to ecosystems and interspecies relations-hence to harvest yields, livestock health, and infectious disease transmission.

3. Tertiary risks to physical and mental health from social and economic disruptions, job losses/changes, and the more ominous risks of health damage from conflict situations driven by climate-related resource shortages (water, food, habitable land).

The climate change process will not be merely a steady change in temperature, rainfall, wind speed and so on. A warmer and wetter world will have an atmosphere packed with more energy, from the warmer air and the latent heat of increased water vapour. Wider-ranging and wilder weather extremes are one consequence (8). Cyclones become more powerful, sea surges and storms become more violent, rainfall and flooding become more extreme, wind-assisted wild fires become fiercer and drought severity increases. Already a widespread upturn in weather disasters is evident, most of them probably amplified by the underlying warming (9).

The broad spectrum of risks to health is illustrated by the increases in mental health problems such as depression, anxiety and Post-Traumatic Stress Disorder (PTSD) following climaterelated disasters such as floods, cyclones, tropical storms, and wild fires. In November 1998, Hurricane Mitch devastated much of Nicaragua and Honduras. A study conducted six months later found that rates of PTSD and depressive disorders were much higher in Nicaragua's worst affected communities than in those less severely affected. Losses of community and livelihoods and uncertainty about the future are important factors (10).

\section{Assigning attribution to climate change}

Seeking evidence of actual health impacts attributable to the climate change that has already occurred is an important research task. It provides a test of the prediction that climate change will in fact have such impacts, and it can yield 'hard' evidence that confirms the potential future seriousness of risks to human health. However, it is not a simple task.

First, human-induced climate change is a relatively slow-moving process, measured on the timescale of a human lifetime. As an environmental health hazard, it is unlike the extremely rapid increase in regional radiation exposure following a nuclear power plant disaster, or the quite rapid marked increase in air pollution levels in Chinese cities over a decade or two. Hence, other than for unusually extreme weather events, clear evidence that the early changes in climate are actually affecting health outcomes is elusive. So, judgements must be made; probabilities estimated; and coherent findings across diverse settings sought. The worldwide strengthening evidence of climate changeinfluenced health impacts includes the following observations:

- Recent uptrends in adverse health impacts from cyclones, storms, wild-fires and flooding around the world
- Increasing numbers of deaths attributable to heatwaves in several countries

- Shifts in the range and seasonality of various climatesensitive infectious diseases (and their vectors): e.g. Lyme disease, malaria

- Climatic contributions to declines in food yields in some regions

- Adverse mental health outcomes in various rural communities affected by drying

An early concern in many parts of the world is the rise in background temperatures and hence in the frequency of temperature extremes. In addition to the upwards shift in temperature, the distribution of daily temperatures at both the hot and cold extremes widens with increased variability, and extremes of heat and cold become more frequent. Indeed, over the past several years, scientific confidence that climate change has begun to influence and amplify such events has strengthened (11). Even so, it is simplistic to attribute the cause of any one extreme weather event exclusively to climate change. Rather, we must understand that it is likely that most such events in future will include a contributory, amplifying, influence from underlying climate change.

While the general community will experience most of the absolute burden of adverse health impact from heat-waves workers in various heat-exposed workplaces, both outdoors and indoors (especially in conditions where there is no air conditioning or other efficient cooling system), are especially vulnerable (12). Indeed, beyond the physiological stress and discomfort and the heightened risk of serious organ damage, extremes of workplace heat exposure can also greatly reduce productivity and economic returns to employers and workers.

\section{Regional risks to population health and well-being}

The various regional environmental manifestations of climate change-extremes of warming or drying, shifts in monsoonal rains and seasons, the heightening of particular extreme weather events (e.g. cyclones, wildfires, flooding, and amplified heatwaves), shortages of freshwater as river flows decrease and evaporation increases, or changes in patterns of infectious disease agent transmission-will impinge differently on widely diverse communities. Poorer and remote groups will be particularly vulnerable, via exposures to the physical hazards of weather disasters, under-nutrition, vector-borne infectious diseases, diarrhoeal diseases, and the consequences of displacement and relocation. Sub-Saharan Africa is at particular risk from the impacts of climate change, particularly from food scarcity due to crop failure, a lack of clean water, and changes in rainfall patterns that result in floods and droughts. Droughts, floods, and seasonal climatic variability can significantly affect access to water and sanitation at local scales, and associated public health burdens. There is evidence that droughts and floods, contribute to seasonal cholera outbreaks in the Bengal Delta region of South Asia, a regional 'hotspot' for diarrhoeal diseases. Monsoon rainfall is expected to increase in the Brahmaputra basin region resulting in a seven-fold increase by 2080 in the number of people flooded annually in South Asia. Such changes will exacerbate the diarrhoeal disease problem, which is being further compounded by rapid urbanisation and the spread of slums around city peripheries with inadequate water and sanitation.

Many of Southeast Asia's coastal cities are vulnerable to sea-level rises and flooding, saltwater intrusion of crops and storms, and 
cyclones. The ongoing increase in ocean acidification is likely to cause a loss of coral reefs, fish habitation, and the natural coastal protection afforded by coral reefs against storms. This poses risks to protein nutrition, livelihoods, and physical safety. Similar concerns apply to many small island states; the Pacific region is particularly vulnerable to extreme weather events, saltwater intrusion into freshwater aquifers and crop soil, and coastal physical safety.

Over at least the next few decades, most of the world's population will continue to depend on small-scale agriculture. This family farm-based form of food production is as vulnerable to climatic fluctuations today as it was historically (13), and entails risks of hunger, child stunting, deaths, impoverishment, and loss of livelihood. Cyclone Ketsana, which hit the central coast of Vietnam in 2009, destroyed several thousand hectares of family-farmed rice fields. Nor, of course, are broad-acre agroindustrial mono-crops immune to climatic adversity and extreme events-but the 'human face' of food shortage and under-nutrition is more distant.

\section{Future global temperatures}

Both observation-based theoretical climate science and the empirical validation of global climate models against the actual recent past record of temperature changes have enabled future projections of global and regional temperatures and rainfall to be made. Increasingly, the projections point to substantial human-caused warming this century that may substantially exceed the officially-proclaimed 'safety limit' of a $2^{\circ} \mathrm{C}$ rise, and reach $4^{\circ} \mathrm{C}$ by later this century (14). That would usher in a hugely environmentally disrupted, wild-weathered, and socially disordered world, and a likely crisis for human health and survival (15).

Most societies will be hard-pressed to prepare for, and cope with, a significant upturn in extreme weather events, especially large-scale events. Already there is evidence of the serious consequences that can flow from weather disasters. The flooding in Pakistan in July 2010 left one-fifth of its land mass underwater and displaced 18 million people. At that same time Russia experienced its hottest summer for 130 years, causing extreme forest and grassland fires that contributed to many thousands of deaths and severe damage to wheat crops (16,17). In 2011, Thailand experienced its most extreme floods in modern times, displacing many thousands of people, causing over 500 deaths (18), destroying at least one-seventh of the national rice crop and causing outbreaks of water-borne infections $(19,20)$. Further, all populations will be at risk from weather-related disasters, irrespective of levels of wealth, infrastructure, support services, and expertise. Consider the damage caused by Super-Storm Sandy in late 2011 in New York City, the protracted drought in the US Midwest during 2009-2011, the extreme recent bushfires in Australia, and the increase in the frequency of prolonged and colder winters in northern Europe as warming of the Arctic region displaces the jet stream, causes stasis of regional air flows, and cold air then streams further south.

Aligning the development and environment-and-climate agendas

In a world marred by persistent poverty and large health inequalities, climate change will amplify those furtherincreasing, for example, the already high rates of diarrhoeal disease and cholera in poor, crowded, and unsewered communities; high rates of malaria in much of Sub-Saharan Africa; widespread under-nutrition and child stunting in South Asia; and high vulnerability to heat-waves in communities with poor-quality housing. A strong message here is that urgent social and economic development is essential to reduce both the health inequities and the associated vulnerability to the adverse health risks from climate change.

Despite the common assumptions, there is no necessary incompatibility between the great and urgent global objectives of development and associated poverty alleviation and of reining in fossil carbon-based energy generation and greenhouse emissions. These two global agendas should, therefore, be aligned (21) - indeed aligned synergistically via a transformative shift to socio-economic development based on successful, job-creating, low-carbon, low environmental intensity methods of production and modes of living.

\section{Conclusion}

The advent of human-induced climate change serves serious notice on the human species that we are now, collectively, living well beyond the limits of Planet Earth-and there will be increasingly serious adverse consequences for the well-being, health, and survival of human populations. Over the past 10,000 years, since early farming appeared, our ancestors have learnt much about the natural world and its resources, and how to harness these to the material benefit and greater security of their societies. But we live within an essentially closed system which, by definition, cannot continue indefinitely to provide, restore, replenish, and absorb.

The great challenge is to find ways to transform much of our culture-our priorities, practices, and technologiesin order to live within those non-negotiable environmental limits, or 'planetary boundaries' (22). One incentive for an international refocusing on attaining a sustainable future for humankind should be the recognition that the changes involved, including most of the actions taken to avert climate change, will confer direct health benefits to the local population -benefits in addition to the lowering of future risks to human health worldwide (23). However, other incentives will also be required since, realistically, most opinion leaders of the world community are committed to the fanciful idea of continued economic 'growth'.

The health sector has an important message to convey: an account of the comparative risks and benefits to population health of enlightened action to avert climate change and achieve sustainable ways of living versus self-interested or complacent inaction.

Ethical issues

Not applicable.

\section{Competing interests}

The author declares that he has no competing interests.

Author's contribution

AJM is the single author of the manuscript.

References

1. Intergovernmental Panel on Climate Change (IPCC). Fifth Assessment Report (Climate Change 2013) Volume 1. Nairobi: UNEP; 2013.

2. Cook J, Nuccitelli D, Green SA, Richardson M, Winkler B, Painting $\mathrm{R}$, et al. Quantifying the consensus on anthropogenic 
global warming in the scientific literature. Environ Res Lett 2013; forthcoming.

3. McMichael AJ. Planetary Overload. Global Environmental Change and the Health of the Human Species. Cambridge: Cambridge University Press; 1993.

4. Global Footprint Network. Atlas of Global Ecological Footprint, 2010. Paris: GFN; 2010.

5. Crutzen PJ. Geology of mankind: the Anthropocene. Nature 2002; 15: 23-6.

6. McMichael AJ. Globalization, climate change and health. N Engl J Med 2013; 368: 1335-43.

7. Butler CD, Harley D. Primary, secondary and tertiary effects of the eco-climate crisis: the medical response. Postgrad Med J 2010; 86: $230-4$

8. Intergovernmental Panel on Climate Change (IPCC). Special Report on Extreme Events (SREX): Managing the Risks of Extreme Events and Disasters to Advance Climate Change Adaptation [internet]. 2012. Available from: http://www.ipcc-wg2.gov/SREX/.

9. Coumou D, Robinson A, Rahmstorf S. Global increase in recordbreaking monthly-mean temperatures. Climatic Change 2013; 118: 771-82.

10. Goenjian AK, Molina L, Alan M. Steinberg AM, et al. Posttraumatic Stress and Depressive Reactions Among Nicaraguan Adolescents After Hurricane Mitch. Am J Psychiatry 2001; 158: 788-94.

11. Schiermeier Q. Climate and weather: Extreme measures: Can violent hurricanes, floods and droughts be pinned on climate change? Scientists are beginning to say yes. Nature 2011; 477: 148-9.

12. Kjellstrom T, Holmer I, Lemke B. Workplace heat stress, health and productivity - an increasing challenge for low and middle-income countries during climate change. Glob Health Action $2009 ; 2$.

13. McMichael AJ. Insights from past millennia into climatic impacts on human health and survival. Proc Natl Acad Sci U S A 2012; 109; 4730-7.
14. Sherwood SC, Bony S, Dufresne JL. Spread in model climate sensitivity traced to atmospheric convective mixing. Nature 2014; 505: $37-42$.

15. McMichael AJ. Health Impacts in Australia in a Four Degree World, In: Christoff P, editor. Four Degrees of Global Warming. Australia in a Hot World. London: Earthscan/Routledge; 2013. p. 151-67.

16. Gilbert N. Russia counts environmental cost of wildfires. Nature News 2010. Available from: http://www.nature.com/news/2010/100812/ full/news.2010.404.html

17. National Oceanic and Atmospheric Administration, US [homepage on the internet]. Natural Variability Main Culprit of Deadly Russian Heat Wave That Killed Thousands. 2011. [updated 2011 March 9; cited 2013 December 20]. Available from: http://www.noaanews. noaa.gov/stories2011/20110309_russianheatwave.html

18. Herald Sun [homepage on the internet]. Death toll from floods nears 1000. 2011. Available from: http://www.heraldsun. com.au/news/world/death-toll-from-floods-nears-1000/storye6frf7lf-1226190452391

19. Agro News [homepage on the internet]. Thailand floods may cut global rice export glut. 2011. Available from: http://news. agropages.com/News/NewsDetail---5826.htm

20. Reuters [homepage on the internet]. Thai floods spread disease. 2011. Available from: http://www.reuters.com/video/2011/11/07/ thai-floods-spread-disease?videold $=224334638$

21. Friel S, Marmot M, McMichael AJ, Kjellstrom T, Vågerö D. Global health equity and climate stabilisation: a common agenda. Lancet 2008; 372: 1677-83.

22. Rockstrom J, Steffen W, Noone K, Persson A, Chapin FS 3rd, Lambin EF, et al. A safe operating space for humanity. Nature 2009; 461: 472-5.

23. McMichael AJ, Butler CD. Promoting global population health while constraining the environmental footprint. Annu Rev Public Health 2011; 32: 179-97. 